\title{
Serum Response Factor and cAMP Response Element Binding Protein Are Both Required for Cocaine Induction of $\Delta$ FosB
}

\author{
Vincent Vialou, ${ }^{\star}$ Jian Feng, ${ }^{\star}$ Alfred J. Robison, Stacy M. Ku, Deveroux Ferguson, Kimberly N. Scobie, \\ Michelle S. Mazei-Robison, Ezekiell Mouzon, and Eric J. Nestler \\ Fishberg Department of Neuroscience and Friedman Brain Institute, Mount Sinai School of Medicine, New York, New York 10029
}

\begin{abstract}
The molecular mechanism underlying induction by cocaine of $\Delta \mathrm{FosB}$, a transcription factor important for addiction, remains unknown. Here, we demonstrate a necessary role for two transcription factors, cAMP response element binding protein (CREB) and serum response factor (SRF), in mediating this induction within the mouse nucleus accumbens (NAc), a key brain reward region. CREB and SRF are both activated in NAc by cocaine and bind to the fos B gene promoter. Using viral-mediated Cre recombinase expression in the NAc of singleor double-floxed mice, we show that deletion of both transcription factors from this brain region completely blocks cocaine induction of $\triangle$ FosB in NAc, whereas deletion of either factor alone has no effect. Furthermore, deletion of both SRF and CREB from NAc renders animals less sensitive to the rewarding effects of moderate doses of cocaine when tested in the conditioned place preference (CPP) procedure and also blocks locomotor sensitization to higher doses of cocaine. Deletion of CREB alone has the opposite effect and enhances both cocaine $C P P$ and locomotor sensitization. In contrast to $\triangle F o s B$ induction by cocaine, $\Delta$ FosB induction in NAc by chronic social stress, which we have shown previously requires activation of SRF, is unaffected by the deletion of CREB alone. These surprising findings demonstrate the involvement of distinct transcriptional mechanisms in mediating $\Delta$ FosB induction within this same brain region by cocaine versus stress. Our results also establish a complex mode of regulation of $\Delta$ FosB induction in response to cocaine, which requires the concerted activities of both SRF and CREB.
\end{abstract}

\section{Introduction}

The nucleus accumbens (NAc) is a key neural substrate for drugs of abuse. One transcription factor implicated in mediating the lasting effects of abused drugs on this brain region is $\Delta$ FosB, a splice product of the fos $B$ gene, which accumulates in NAc uniquely in response to repeated drug exposure and contributes significantly to the altered patterns of gene expression seen in the drug-treated state (McClung and Nestler, 2003; Renthal et al., 2009). $\Delta$ FosB has been proposed as a potential molecular switch guiding the transition from recreational drug use to the chronically addicted state, because its accumulation in NAc enhances rewarding responses to several drugs of abuse (Nestler, 2008). However, the mechanism responsible for drug-induced $\Delta$ FosB accumulation in NAc remains unknown.

Exposure to cocaine activates several intracellular signaling cascades in NAc (Matamales and Girault, 2011), including the

Received March 20, 2012; revised April 10, 2012; accepted April 13, 2012.

Author contributions:V.V., J.F., and E.J.N. designed research; V.V., J.F., A.J.R., S.M.K., D.F., M.S.M.-R., K.N.S., and E.M. performed research; V.V., J.F., S.M.K., and K.N.S. analyzed data; V.V., J.F., and E.J.N. wrote the paper.

This work was supported by grants from the National Institute on Drug Abuse and National Institute of Mental Health.

*V.V. and J.F. contributed equally to this work.

Correspondence should be addressed to Eric J. Nestler, Fishberg Department of Neuroscience and Friedman Brain Institute, Mount Sinai School of Medicine, One Gustave L. Levy Place, Box 1065, New York, NY 10029-6574. E-mail: eric.nestler@mssm.edu.

DOI:10.1523/JNEUROSCI.1381-12.2012

Copyright $\odot 2012$ the authors $\quad 0270-6474 / 12 / 327577-08 \$ 15.00 / 0$
cAMP-protein kinase A (PKA), $\mathrm{Ca}^{2+}$-CaMKII (Loweth et al., 2008; Robison et al., 2011), and extracellular signal regulated kinase (ERK) (Valjent et al., 2000) pathways. These pathways lead to the phosphorylation of several transcription factors, in particular, serum response factor (SRF) and cAMP response element binding protein (CREB). Both of these activity-dependent transcription factors have been implicated in the induction of several immediate early genes, including $c$-fos, fos $B$, egrl, and arc (Knöll and Nordheim, 2009). We previously demonstrated that SRF is required for $\triangle \mathrm{FosB}$ induction in NAc by chronic social defeat stress (Vialou et al., 2010b). However, we and others have found that SRF is not required for the induction by cocaine of $\triangle \mathrm{FosB}$ within this same brain region (Parkitna et al., 2010; Vialou et al., 2010b).

Here we demonstrate that the selective knock-out of both CREB and SRF from the adult NAc blocks $\triangle$ FosB induction by cocaine, whereas the knock-out of CREB alone (like the knockout of SRF alone) has no effect. Chromatin immunoprecipitation (ChIP) confirms that both transcription factors are enriched at the $f \circ s B$ gene promoter after cocaine exposure. Consistent with these molecular data and the known ability of $\Delta$ FosB to mediate sensitized drug responses (Nestler, 2008), we show further that the loss of $\Delta$ FosB accumulation achieved via the double knockout of CREB and SRF from NAc is associated with decreased rewarding and locomotor actions of cocaine, effects not seen in the single knock-outs. Finally, we demonstrate that $\Delta$ FosB induction by chronic social defeat stress is unaffected by the deletion of 
CREB alone from NAc, further establishing distinct mechanisms of $\Delta$ FosB regulation by stress versus cocaine.

This novel interplay between CREB and SRF in the context of cocaine suggests that the two activity-dependent transcription factors can compensate for each other under certain circumstances and may represent an important homeostatic mechanism regulating an individual's sensitivity to drugs of abuse.

\section{Materials and Methods}

Animals. Eight-week-old C57BL/6J male mice (The Jackson Laboratory) were used. All mice were habituated to the animal facility for $\geq 1$ week before experimental manipulations and were maintained at $23-25^{\circ} \mathrm{C}$ on a $12 \mathrm{~h} \mathrm{light/dark} \mathrm{cycle} \mathrm{(lights} \mathrm{on} \mathrm{from} \mathrm{7:00} \mathrm{A.M.)} \mathrm{with} \mathrm{ad} \mathrm{libitum} \mathrm{access} \mathrm{to}$ food and water. Experiments were conducted in accordance with guidelines of the Society for Neuroscience and the institutional animal care and use committee (IACUC) at Mount Sinai.

$\mathrm{Sr}^{f l / f l}$ and $\mathrm{Creb}^{f l / f l}$ mice were generated as described previously (Ramanan et al., 2005; Covington et al., 2011). Double-floxed mice were obtained by crossing the two lines. NAc-specific knock-out of SRF and CREB was achieved by injecting an adeno-associated virus (AAV) vector expressing Cre recombinase fused to green fluorescent protein (AAVCre-GFP) or AAV-GFP as a control as described previously (Maze et al., 2010; Vialou et al., 2010b). Briefly, mice were anesthetized using a mixture of ketamine $(10 \mathrm{mg} / \mathrm{kg})$ and xylazine $(1 \mathrm{mg} / \mathrm{kg})$, and the following stereotaxic coordinates were used for viral delivery: +1.6 (anterior/posterior), +1.5 (lateral), -4.4 (dorsal/ventral) at an angle of $10^{\circ}$ from the midline (relative to bregma). A total of $0.5 \mu$ l of purified virus was delivered bilaterally over a $5 \mathrm{~min}$ period $(0.1 \mu \mathrm{l} / \mathrm{min})$, followed by $5 \mathrm{~min}$ of rest. Mice were tested 3 weeks after surgery, and viral injection sites were confirmed for all mice using standard histological methods. No overlap between Cre expression and SRF or CREB staining was observed by immunohistochemistry (see Fig. 1), thus confirming the knock-outs.

Conditioned place preference. Conditioning was performed exactly as described previously (Vialou et al., 2010b) and consisted of two rounds of training for cocaine and saline. Briefly, 3 weeks after intra-NAc injections of AAV-GFP or AAV-Cre-GFP, mice were placed into the middle chamber of our conditioning apparatus, which consist of two contextually distinct chambers on either side (Med Associates). There are no group differences in bias for either chamber, although conditioning groups were further balanced to adjust for any small chamber bias that might still exist. On 2 successive days, mice were injected with saline in the morning (between 8:00 A.M. and 10:00 A.M.) and confined to one chamber for 30 min, and then the mice were injected with cocaine in the afternoon (between 3:00 P.M. and 5:00 P.M.) and confined for $30 \mathrm{~min}$ to the other chamber, equaling a total of two rounds of association training per treatment (two saline and two cocaine pairings). On the test day, mice were placed back into the apparatus without treatment for 20 min (between 12:00 P.M. and 2:00 P.M.) and evaluated for side preference. Locomotor responses to cocaine were assessed via beam breaks in the cocaine-paired chambers to ensure effectiveness of drug treatment. For all groups, baseline locomotion in response to saline was assessed to ensure that locomotion was not affected by viral treatment. Three doses of cocaine $(4,7.5$, and $12 \mathrm{mg} / \mathrm{kg}$, i.p.) were tested in separate groups of mice. A vehicletreated group was included as an additional control.

Locomotor sensitization. Locomotor activity was recorded during the pairing sessions of the conditioned place preference (CPP) experiments. To extend this analysis beyond two exposures to cocaine, we injected the mice with one additional dose of cocaine $(12 \mathrm{mg} / \mathrm{kg}$, i.p.) while the mice were confined to their cocaine-paired compartment in the CPP apparatus. A significant increase in locomotor activity between the first and last cocaine exposures confirmed sensitization to the drug.

Immunohistochemistry. Validation of knock-outs and quantification of $\Delta$ FosB-immunopositive cells were performed as described previously (Vialou et al., 2010b; Covington et al., 2011). The number of GFPimmunopositive cells, counted as negative and positive for $\Delta$ FosB (1: 1000, catalog \#sc-48; Santa Cruz Biotechnology), was quantified in multiple images for each mice, with mean values subsequently calculated for each mice. Each mice was considered an individual observation for statistical analysis.

Western blotting. Mice received seven daily intraperitoneal injections of saline or cocaine $(20 \mathrm{mg} / \mathrm{kg})$ in their home cage. The acute group received $6 \mathrm{~d}$ of saline and a single dose of cocaine on day 7. Mice were killed $1 \mathrm{~h}$ after the final injection, and NAc punch dissections were processed as described previously (Vialou et al., 2010b). Western blots were probed using an antibody to phospho-Ser103-SRF (1:1000, catalog \#4261; Cell Signaling Technology), SRF (1:1000; Santa Cruz Biotechnology), phospho-Ser133-CREB (1:1000, catalog \#9198; Cell Signaling Technology), CREB (1:1000, catalog \#06-863; Millipore), or GAPDH (1:1500, catalog \#ab9483; Abcam) and were then scanned and quantified using Odyssey imaging system (LI-COR Biosciences).

ChIP. ChIP was performed as described previously (Lee et al., 2006; Renthal et al., 2009; Vialou et al., 2010b) with minor modifications. The antibodies used were anti-phospho-SRF (catalog \#4261; Cell Signaling Technology), anti-phospho-CREB (catalog \#06-519; Millipore), antiCREB (catalog \#31387; Abcam), and anti-nuclear factor $\kappa \mathrm{B}(\mathrm{NF} \kappa \mathrm{B}) \mathrm{p} 65$ (catalog \#7970; Abcam). In brief, bilateral NAc punches from saline- or cocaine-treated mice were collected $1 \mathrm{~h}$ after the last injection. They were then flash frozen and stored at $-80^{\circ} \mathrm{C}$ until use. For ChIP, tissue was crosslinked in $1 \%$ formaldehyde for $12 \mathrm{~min}$, followed by glycine incubation for $5 \mathrm{~min}$. Extracts were homogenized, lysed in lysis buffers (http://jura.wi.mit.edu/young_public/hES_PRC/ChIP.html), and sonicated using a Bioruptor (UCD-400 TM; Diagenode) for $\sim 40$ cycles ( $30 \mathrm{~s}$ on, $30 \mathrm{~s}$ off) with continuous cooling of the water bath. The resulting lysates were incubated overnight at $4^{\circ} \mathrm{C}$ with Dynal magnetic beads that had been preincubated with the appropriate antibody. Beads were then washed eight times with RIPA buffer and one time with Tris-EDTA containing $50 \mathrm{~mm} \mathrm{NaCl}$. The samples were eluted from the beads by heating at $65^{\circ} \mathrm{C}$ and reverse crosslinked by overnight incubation at $65^{\circ} \mathrm{C}$. One hundred microliters of input lysate were also reserved after sonication and treated for crosslink reversal. After RNAse A and proteinase K treatments, the DNAs were purified by Qiagen quick PCR purification kit.

Binding to the fos $B$ promoter was determined by $\mathrm{qPCR}$ using primers spanning a region of the promoter containing a serum response element (SRE) and a cAMP response element (CRE). The following primers were used: fos $B$, forward, CCCTCTGACGTAATTGCTAGG and reverse, CCAA GGCTGCGTTCTGAG; egr2, forward, GTGAAGGAGGGGTTTGACTG and reverse, ATTCCGGTTCTCCGAGACTT; grial, forward, GGAATCAG CGCAAAATGACT and reverse, TGCAGGGTGCAGGAATCTAT.

Statistical analyses. Data are expressed as mean \pm SEM. One-way ANOVAs were used to compare means across saline, acute cocaine, and chronic cocaine groups in biochemical analyses. Two-way ANOVAs were used to compare $\Delta$ FosB induction by cocaine in SRF-CREB double knock-out and CREB single knock-out mice, as well as locomotor sensitization to cocaine. Student's $t$ tests were used to compare means in the effect of SRF-CREB and CREB knock-outs on cocaine place conditioning and ChIP. Differences between experimental conditions were considered statistically significant when $p<0.05$.

\section{Results}

\section{Effect of CREB and SRF knock-out on cocaine induction of $\triangle$ FosB in NAc}

We previously observed that SRF is not required for $\Delta$ FosB induction in NAc by cocaine (Vialou et al., 2010b). Because the fos $B$ promoter contains a CRE, as well as an SRE (Lazo et al., 1992), recognized, respectively, by $\mathrm{CREB}$ and $\mathrm{SRF}$, we initially hypothesized that CREB might mediate $\Delta$ FosB induction by cocaine. To test this hypothesis, we used $C r e b^{f l f l}$ mice to generate a conditional knock-out of CREB in the NAc of adult mice (Covington et al., 2011). $C r e b^{f l / f l}$ mice were stereotaxically injected intra-NAc with AAV-Cre-GFP or AAV-GFP (Fig. 1). NAc-specific knockout of CREB induced by AAV-Cre-GFP was confirmed immunohistochemically (data not shown) (Covington et al., 2011). We then performed quantitative immunohistochemistry for $\Delta$ FosBexpressing cells in NAc of saline- or cocaine-treated $\mathrm{Creb}^{f l / f l}$ mice 
A1 Floxed CREB
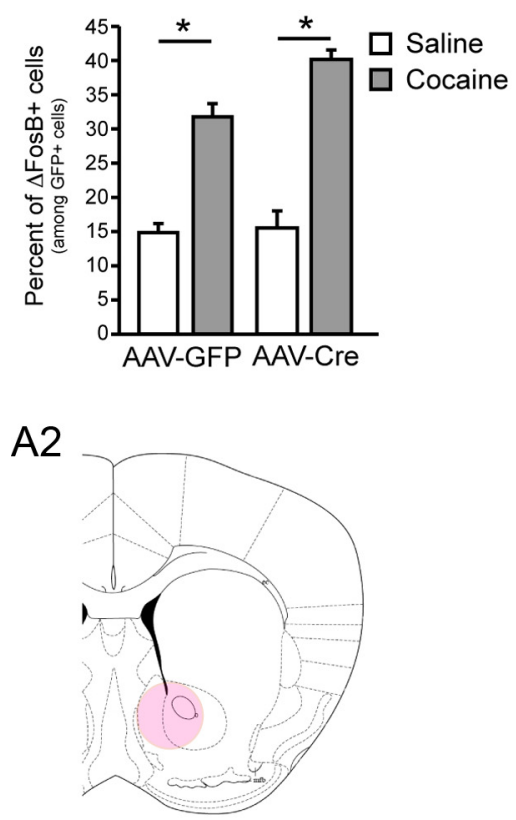

Area where the needle placements were found.

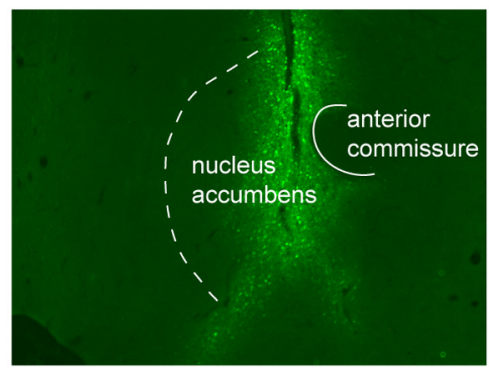

B1 Floxed CREB/SRF
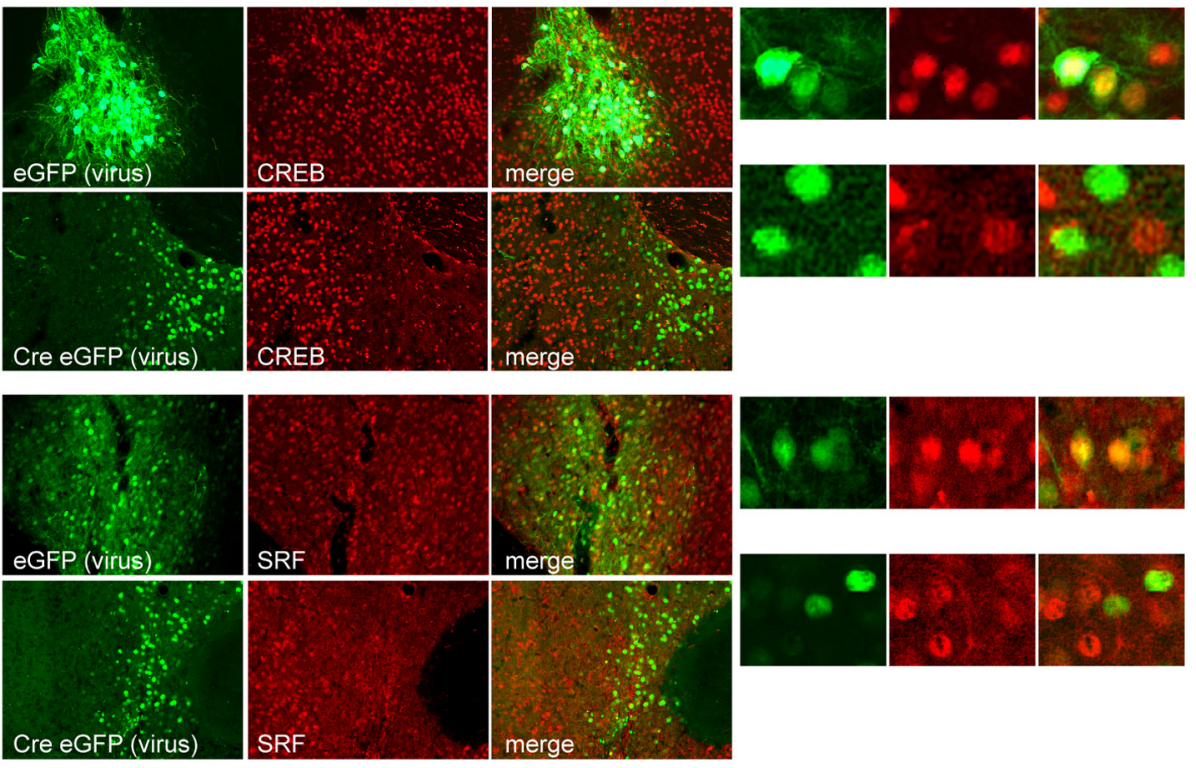

B2

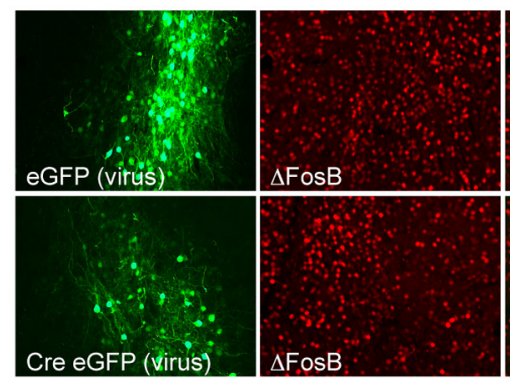

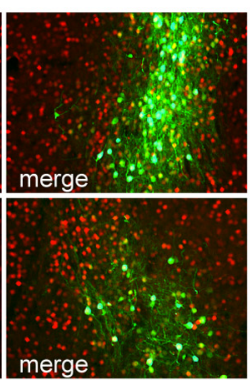

B3

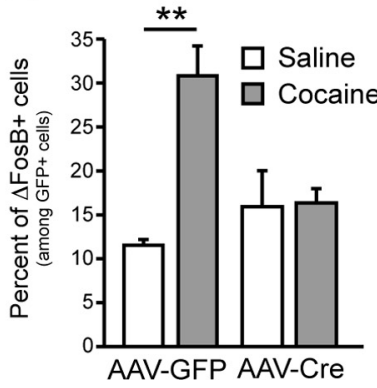

Figure 1. CREB and SRF mediate $\triangle F$ FosB induction by chronic cocaine. $A, \triangle F$ FosB accumulation, measured immunocytochemically, after chronic cocaine is unaffected by NAc-specific knock-out of CREB. B1, Injection of AAV-Cre-GFP into NAc of Creb ${ }^{f / f f}-S f^{f / / f l}$ mice results in the knock-out of CREB and SRF protein in Cre-expressing neurons. Injection of AAV-GFP has no discernable effect. B2, B3, Such selective knock-out of CREB and SRF from NAc completely blocks $\triangle$ FosB induction in NAc by chronic cocaine ( $n=4$ per group). ${ }^{*} p<0.05$; ${ }^{* *} p<0.01$ versus saline.

injected with AAV-Cre-GFP or AAV-GFP. Chronic cocaine induced an equivalent increase in $\triangle \mathrm{FosB}$ expression in NAc of both groups of mice (Fig. 1A-1), demonstrating that the activity of CREB alone is not required for $\triangle$ FosB induction.

Given the lack of effect of knocking out SRF or CREB on cocaine induction of $\Delta$ FosB in NAc, we next hypothesized that perhaps the two transcription factors can compensate for the loss of the other and that both might be required for $\Delta$ FosB induction. To test this alternative hypothesis, we injected doublefloxed $S r f^{f l f l}-\mathrm{Creb}^{f l / f l}$ mice intra-NAc with AAV-Cre-GFP or AAV-GFP. NAc-specific knock-out of both CREB and SRF driven by AAV-Cre-GFP was confirmed immunohistochemically: there was zero overlap between CREB or SRF staining and Cre expression (Fig. $1 B-1, B-2$ ). We then treated double-floxed mice, injected intra-NAc with AAV-Cre-GFP or AAV-GFP, with repeated saline or cocaine and quantified $\Delta$ FosB expression. Local knock-out of both transcription factors completely blocked the ability of repeated cocaine to induce $\Delta$ FosB (virus $\times$ treatment interaction, $F_{(1,14)}=12.33, p<0.01$; Bonferroni's post hoc test, $p<0.01$ vs saline) (Fig. $1 B-2, B-3$ ). Interestingly, neither the single knock-out of CREB or SRF nor the double knock-out of both factors affected baseline levels of $\Delta$ FosB (see Discussion).

\section{Cocaine regulation of CREB and SRF in NAc}

To understand the mechanism by which CREB and SRF mediate $\Delta$ FosB induction by cocaine, we evaluated the levels of the active, phosphorylated forms of the two factors. Chronic cocaine increased phospho-SRF $\left(F_{(2,21)}=8.13, p<0.01 ; t\right.$ tests with a Bonferroni's correction, $p<0.01$, chronic vs saline), as well as phospho-CREB in NAc $\left(F_{(2,22)}=2.072, p>0.05 ; t\right.$ tests, $t_{(13)}=$ $2.173, p<0.05$, chronic vs saline) (Fig. $2 A, B$ ), the latter consistent with published reports for phospho-CREB (Cole et al., 1995; Simpson et al., 1995; Turgeon et al., 1997; Marin et al., 2009). There were nonsignificant trends for similar effects of acute cocaine. Data were analyzed as ratios of phospho-protein to GAPDH, because the phosphorylated forms of the proteins are biologically active; hence, the absolute levels of their phospho forms represent the best measure of their transcriptional activity. We next used ChIP to examine whether the binding of phosphoSRF or phospho-CREB to the fosB gene promoter was altered after chronic cocaine. Such cocaine treatment enhanced the binding of both transcription factors to the fos $B$ promoter in NAc compared with saline-treated mice (phospho-SRF, $t_{(21)}=2.476$, $p<0.05$; phospho-CREB, $\left.t_{(10)}=2.216, p<0.05\right)$ (Fig. $3 A$ ). We previously found no difference in the binding of total SRF after 
cocaine exposure (Vialou et al., 2010b), suggesting that it is the activated form of SRF that becomes enriched at the fos $B$ promoter after cocaine. Similar data were obtained for CREB: despite increased binding of phospho-CREB to the fos $B$ gene, cocaine did not influence levels of total CREB binding (Fig. 3A). This is consistent with the view that dephosphoCREB may be bound to gene promoters in the basal state, whereupon it is activated by phosphorylation. The situation for SRF may be more complicated in that SRF phosphorylation and activation affects both its binding to DNA and transcriptional activity (Janknecht et al., 1992; Iyer et al., 2003).

A cocaine-induced increase in phosphoCREB binding was also found at the glur1 ( gluA1) gene promoter, a known target of CREB (Borges and Dingledine, 2001; Olson et al., 2005) $\left(t_{(9)}=2.220, p<0.05\right)$ (Fig. 3B). Conversely, a cocaine-induced increase in phospho-SRF binding was observed at the egr2 gene promoter, a known target of SRF (Ramanan et al., 2005; Parkitna et al., 2010) $\left(t_{(10)}=2.715, p<0.05\right)$ (Fig. 3C). Cocaine is also known to induce another transcription factor, $\mathrm{NF} \kappa \mathrm{B}$, in $\mathrm{NAc}$ (Russo et al., 2009), but we observed no change in the binding of $\mathrm{NF} \kappa \mathrm{B}$ to the fos $B$ gene promoter (Fig. $3 A$ ). These experiments demonstrate the specificity of our ChIP assays and further support a unique coordinated role for phospho-CREB and phospho-SRF in controlling $\Delta$ FosB induction by cocaine.

\section{Behavioral effects of cocaine on CREB and SRF knock-out from NAc}

Our results establish that CREB contributes to $\triangle \mathrm{FosB}$ induction in NAc by repeated cocaine. However, previous work has demonstrated opposite functional roles for CREB versus $\Delta$ FosB in the regulation of cocaine reward, with $\mathrm{CREB}$ reducing drug reward and $\Delta$ FosB increasing it (Nestler, 2001). To gain insight into these phenomena, we studied rewarding responses to cocaine by using of CPP assays, in mice with single CREB knock-out or double CREB-SRF knock-out from NAc. We had shown previously that single SRF knock-out from this brain region has no effect on cocaine place conditioning (Vialou et al., 2010b).

Deletion of CREB only in NAc increased cocaine place preference $\left(t_{(19)}=1.955, p<0.05\right)$ (Fig. $4 A$ ): AAV-GFP-injected $\mathrm{Creb}^{f l f l}$ mice showed no preference for a moderate dose of cocaine $(7.5 \mathrm{mg} / \mathrm{kg})$, whereas AAV-Cre-GFP-injected $C r e b^{f l / f l}$ mice showed robust place conditioning. Dose-response analyses revealed that both control and CREB-selective knock-out mice spend significantly more time in the environment paired with higher doses of cocaine $(12 \mathrm{mg} / \mathrm{kg})$ but show no preference for a lower dose of cocaine ( $4 \mathrm{mg} / \mathrm{kg}$ ) (Fig. $4 A$ ). These results are consistent with the increased sensitivity to cocaine observed after overexpression of a dominant-negative CREB mutant in this brain region (Carlezon et al., 1998; Barrot et al., 2002; Sakai et al., 2002). In striking contrast, double CREB-SRF floxed mice injected with AAV-Cre-GFP displayed reduced place conditioning to a moderate dose of cocaine $(7.5 \mathrm{mg} / \mathrm{kg})$ compared with AAVGFP-injected mice $\left(t_{(34)}=1.757 ; p<0.05\right)$ (Fig. $4 B$ ). Such a decrease in cocaine sensitivity was also observed with a low dose
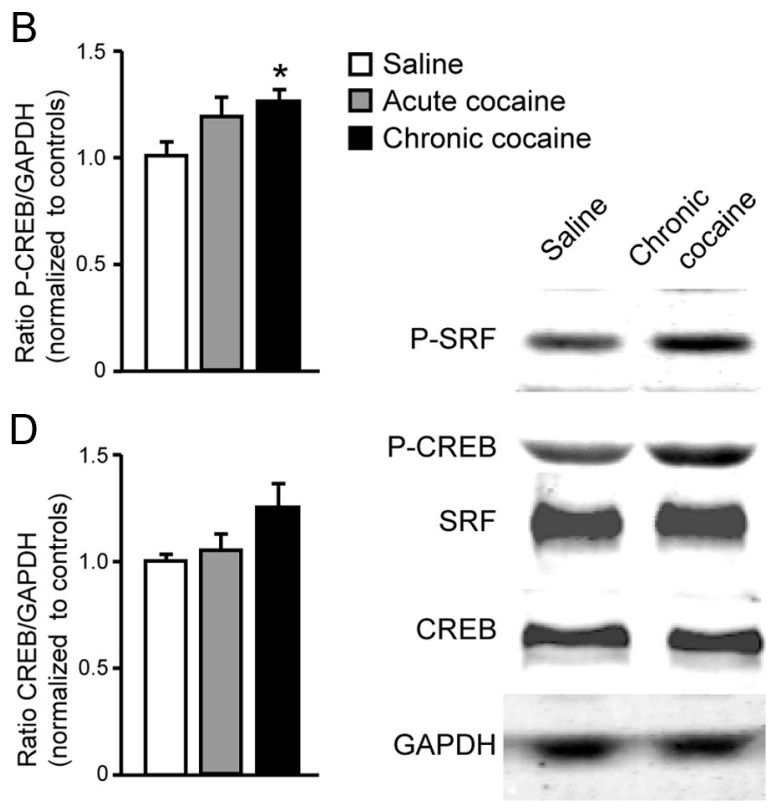

D

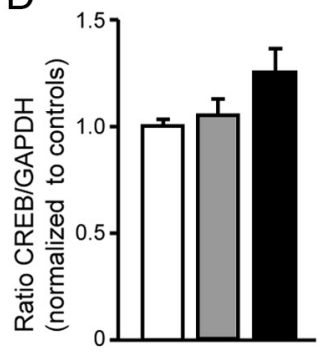

Figure 2. Cocaine-induced increases in phospho-SRF and phospho-CREB correlate with increased $\triangle$ FosB expression in NAC. Chronic cocaine increases phospho-SRF $(\boldsymbol{A})$ and phospho-CREB $(\boldsymbol{B})$ protein levels in NAc $1 \mathrm{~h}$ after the last injection detected by Western blots. Acute cocaine induces similar changes, although they are not significant. $\boldsymbol{C}, \boldsymbol{D}$, No differences were observed in total per group). ${ }^{*} p<0.05$ versus saline.

of cocaine $(4 \mathrm{mg} / \mathrm{kg})$ but was not significant $\left(t_{(19)}=1.488, p=\right.$ 0.077). At a high dose of cocaine $(12 \mathrm{mg} / \mathrm{kg})$, double CREB-SRF floxed mice given AAV-Cre-GFP or AAV-GFP displayed equivalent place preferences (Fig. $4 B$ ). These findings are consistent with the loss of $\Delta$ FosB induction in the double knock-outs: previous observations established that overexpression of $\Delta$ FosB in NAc increases the rewarding effects of cocaine, whereas expression of a dominant-negative antagonist exerts the opposite effect (Kelz et al., 1999; Colby et al., 2003; Peakman et al., 2003).

Another behavioral effect of repeated exposure to cocaine is the progressive enhancement in the hyperlocomotor effects elicited by the drug, termed locomotor sensitization. NAc-selective deletion of CREB increased locomotor sensitization to cocaine $\left(F_{(3,72)}=4.164, p<0.01\right.$; Bonferroni's post hoc test, $p<0.001 \mathrm{vs}$ GFP, vs saline) (Fig. 4C): AAV-GFP-injected Creb ${ }^{f l f l}$ control mice showed significant sensitization for a high dose of cocaine $(12 \mathrm{mg} / \mathrm{kg})\left(t_{(14)}=1.833, p<0.05\right)$, and this sensitization was significantly greater in AAV-Cre-GFP-injected Creb ${ }^{f l / f l}$ mice $\left(t_{(15)}=2.480, p<0.05\right)$. This effect of the local CREB knock-out is consistent with the potentiated cocaine CPP observed under these conditions. Conversely, double CREB-SRF mice injected with AAV-Cre-GFP showed no locomotor sensitization (Fig. $4 D)$, whereas their GFP-injected counterparts did $\left(F_{(3,60)}=\right.$ 0.2100 , main effect of virus and drug; Bonferroni's post hoc test, $p<0.001$ vs saline). The lack of cocaine sensitization could be explained by the loss of $\Delta$ FosB induction in the double knockouts, because $\Delta$ FosB overexpression in NAc increases locomotor sensitization to cocaine (Kelz et al., 1999; Ulery et al., 2008). NAc-specific knock-out of CREB alone or both CREB and SRF had no effect on acute locomotor responses to cocaine.

\section{Behavioral effects of chronic stress on CREB knock-out from NAc}

We recently showed that chronic exposure to social defeat stress induces $\Delta$ FosB in the NAc through SRF: induction was blocked completely in $S r f^{f l / f l}$ mice injected intra-NAc with AAV-Cre-GFP 
A
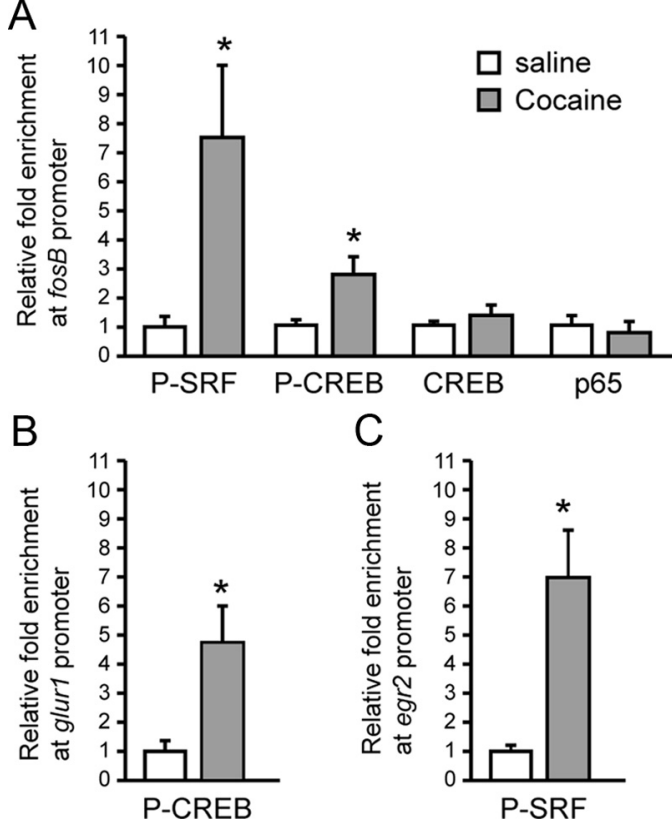

$\mathrm{C}$

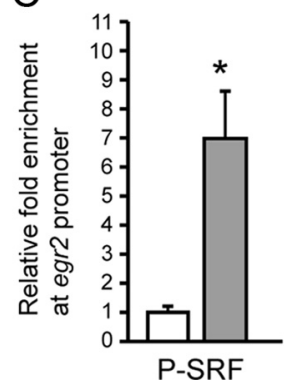

Figure 3. Chronic cocaine increases the binding of phospho-SRF and phospho-CREB to the fos $B$ gene promoter. $A$, ChIP demonstrates enrichment of phospho-SRF and phospho-CREB at the fos $B$ gene promoter after chronic cocaine. No significant change was observed for total CREB or NF $\kappa B / p 65$ binding. $B, C$, Phospho-SRF and phospho-CREB display increased binding at the promoter of their respective target genes, egr2 and glur $1\left(n=6-12\right.$ per group). ${ }^{*} p<0.05$ versus saline.

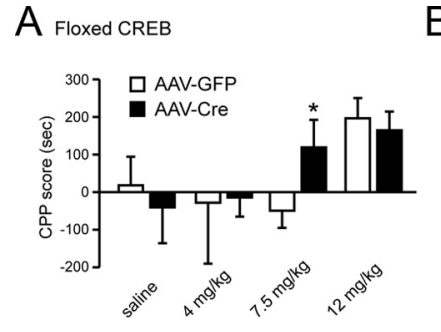

C Floxed CREB - cocaine $12 \mathrm{mg} / \mathrm{kg}$

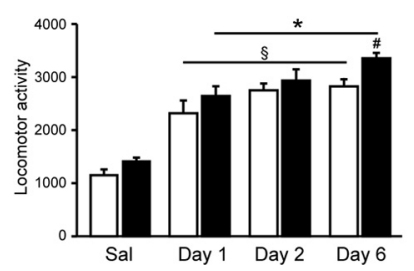

$\mathrm{D}$ r

B Floxed CREB/SRF

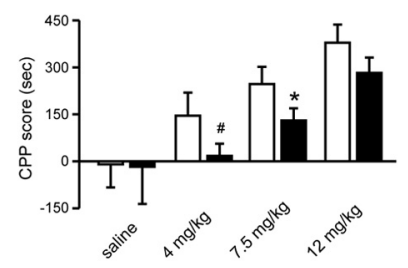

Floxed CREB/SRF - cocaine $12 \mathrm{mg} / \mathrm{kg}$

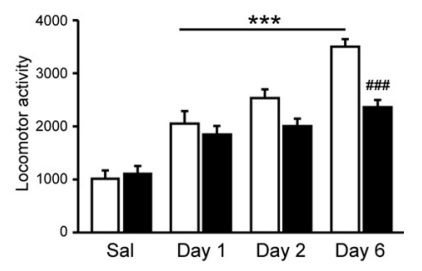

Figure 4. Loss of CREB and SRF decreases behavioral responses to cocaine. $A$, Local deletion of CREB from NAc increases (PP to moderate doses of cocaine ( $n=8-10$ per group). No differences were seen at low and high dose of cocaine. $\boldsymbol{B}$, In contrast, local knock-out of SRF and CREB from NAC reduces place conditioning to cocaine at low and moderate dose but not high dose of cocaine. Note that AAV-GFP-injected double-floxed mice show stronger cocaine place conditioning at every dose tested compared with AAV-GFP-injected $\mathrm{Creb}^{f / / f}$ mice because of differences in genetic background. All experiments were done in parallel on the same day in independent batches of animals. ${ }^{*} p<0.05$, ${ }^{\#} p=0.06$ versus AAV-GFP. C, Loss of CREB resulted in an increase cocaine sensitization compared with controls ( $n=10$ per group). $\boldsymbol{D}$, Consistent with the decrease preference for cocaine, SRF and CREB local knock-out reduced the locomotor sensitization to cocaine ( $n=10$ per group). Note that both selective manipulation did not affect acute response to cocaine at $12 \mathrm{mg} / \mathrm{kg}^{*} p<0.05,{ }^{* * *} p<$ 0.001 versus cocaine day $1 ;{ }^{\#} p<0.05,{ }^{\# \# \#} p<0.001$ versus AAV-GFP cocaine day $3 ;{ }^{\S} p<0.05$ versus AAV-GFP cocaine day 1.

(Vialou et al., 2010b). In other studies, CREB was implicated in the defeat stress-induced depressive-like phenotype, which was attenuated in mice with a local knock-out of CREB from this brain region (Covington et al., 2011). Because SRF activation and
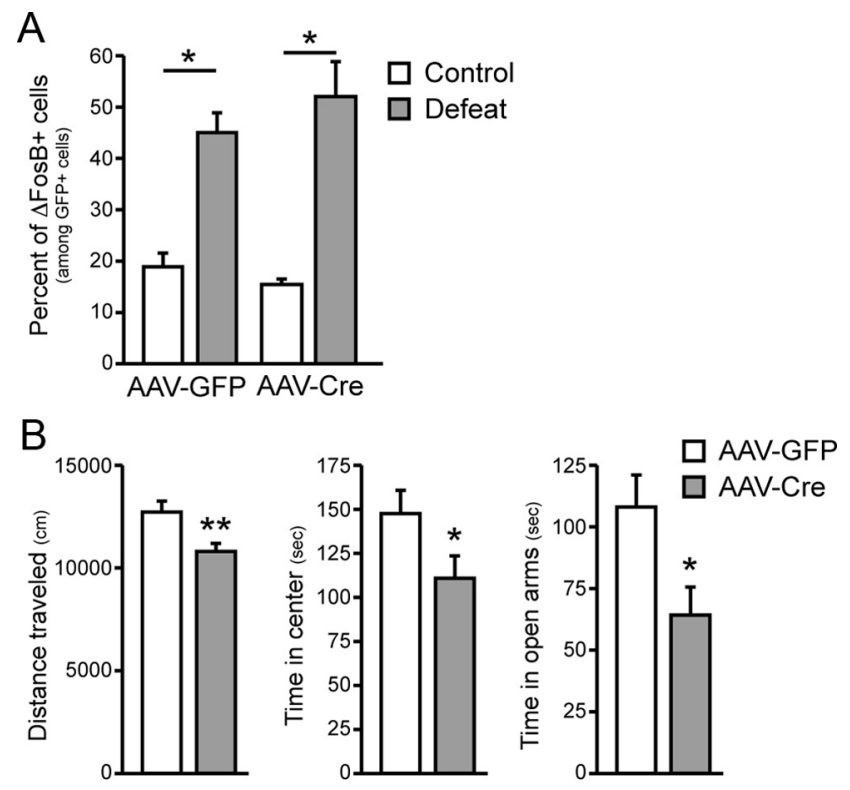

Figure 5. Effect of NAc-specific CREB knock-out on stress-induced $\Delta$ FosB accumulation and anxiety-like behavior. $A$, NAc-specific CREB knock-out has no effect on $\Delta$ FosB accumulation after exposure to chronic social defeat stress. ${ }^{*} p<0.05$ versus control. $\boldsymbol{B}$, Local deletion of CREB from NAc decreases locomotor activity and time spent in the center of a novel open field, as well as time spent in the open arms in the 0 -maze. ${ }^{*} p<0.05,{ }^{* *} p<0.01$ versus AAV-GFP.

$\Delta$ FosB induction by chronic defeat stress have both been shown previously to mediate resilience to the deleterious effects of chronic stress (Vialou et al., 2010a), we hypothesized that CREB activation by defeat stress is not required for $\Delta \mathrm{FosB}$ induction under these conditions. To test this hypothesis, we subjected $\mathrm{Creb}^{f l f l}$ mice, injected intra-NAc with AAV-Cre-GFP or AAVGFP, to chronic social defeat stress and examined $\triangle$ FosB induction. As expected, local knock-out of CREB alone did not attenuate $\Delta$ FosB induction in NAc by social defeat stress (Fig. $5 A$ ). To more completely characterize the behavioral phenotype obtained on NAc-selective knock-out of CREB, we analyzed anxiety-like behavior in the open-field and O-maze tests. We found that loss of CREB from NAc was anxiogenic in both assays (Fig. 5B), consistent with the behavioral effects of overexpressing dominant-negative mutant CREB in this brain region (Barrot et al., 2002).

\section{Discussion}

This study identified both CREB and SRF as upstream mediators of $\Delta$ FosB induction in NAc by chronic cocaine. We show that repeated exposure to cocaine activates both CREB and SRF in this brain region and that both factors display increased binding to the $f o s B$ gene promoter under these conditions. Although deletion of each transcription factor alone from NAc did not affect cocaine induction of $\Delta$ FosB, deletion of both CREB and SRF completely blocked this induction. These findings support a complex mode of regulation of $\Delta$ FosB induction in response to cocaine exposure, which requires the concerted activities of both transcription factors. Our results also highlight the distinct molecular mechanisms underlying the induction of $\Delta$ FosB within NAc in response to repeated cocaine versus repeated stress.

\section{Distinct roles of CREB, SRF, and $\triangle F$ Fos $B$ in addiction and stress models}

A large literature supports the view that CREB activation in NAc mediates neural adaptations by drugs of abuse that oppose drug 
reward (Carlezon et al., 2005; Blendy, 2006; Dinieri et al., 2009). CREB is also activated in this brain region by chronic stress, in which it contributes to depression-like maladaptations (Barrot et al., 2002; Carlezon et al., 2005; Covington et al., 2011). More recently, CREB activation in NAc has been shown to also enhance motivation to self-administer cocaine (Larson et al., 2011). However, given the preponderance of evidence that CREB activation in this brain region induces a negative emotional state, our hypothesis is that CREB increases drug self-administration via a process of negative reinforcement (Larson et al., 2011). In contrast to CREB, we demonstrated recently that SRF is activated in NAc by chronic stress but mediates a pro-resilience effect in part through the induction of $\Delta$ FosB (Vialou et al., 2010b).

We show in the present study that deletion of both SRF and CREB from NAc reduces cocaine place conditioning and locomotor sensitization, consistent with the loss of $\Delta$ FosB induction seen under these conditions. In dramatic contrast, we show that the deletion of CREB alone enhances cocaine place conditioning and locomotor sensitization, and we demonstrated previously that deletion of SRF alone had no effect on behavioral responses to cocaine (Vialou et al., 2010b). The enhancement of behavioral responses to cocaine in mice lacking CREB only in NAc is consistent with previous studies showing that overexpression of a dominant-negative CREB mutant increases cocaine reward (Carlezon et al., 1998; Barrot et al., 2002), thereby validating these previous overexpression studies with our current deletion of endogenous CREB expression. In contrast to our data, knock-out of CREB from the entire brain at early developmental stages showed no effect on cocaine CPP (Valverde et al., 2004), suggesting opposite contributions of other brain regions or compensatory mechanisms during development. These considerations emphasize the importance of using brain-region-specific manipulations in adult animals. The finding of qualitatively opposite behavioral effects on double knock-out of CREB and SRF versus single knock-out of CREB is striking. Our data support a scheme wherein CREB knock-out alone does not affect $\Delta$ FosB induction but blocks numerous adaptations to cocaine that normally serve to blunt cocaine responses, consistent with previous investigations (McClung and Nestler, 2003; Dong et al., 2006). In contrast, knock-out of SRF and CREB blocks $\triangle$ FosB induction and presumably other gene targets that require both transcription factors, which mediate sensitized drug responses; the loss of these pro-sensitization mechanisms then predominates and leads to diminished drug responsiveness.

Results of the present study likewise clarify the actions of CREB in stress models. We have shown previously that knockdown of CREB function in NAc exerts pro-resilience and antidepressant-like effects in several behavioral models (Carlezon et al., 2005; Covington et al., 2011). This is congruent with the lack of effect of CREB knock-out from NAc on $\Delta$ FosB accumulation after stress exposure, because $\Delta$ FosB has been shown to mediate proresilience and antidepressant-like behaviors (Vialou et al., 2010a,b).

We have hypothesized that the opposite effects of CREB and $\Delta$ FosB on drug reward reflect their involvement in different aspects of addiction: for example, CREB might underlie the early dysphoric phase of withdrawal, whereas $\Delta$ FosB might mediate more prolonged drive for drug use (Nestler, 2004). Such behavioral data are consistent with the observation that the two transcription factors regulate primarily distinct sets of target genes in NAc, with opposite effects exerted on the smaller subset of genes regulated in common (McClung and Nestler, 2003; Renthal et al., 2009). Early progress is being made in identifying some of the target genes in NAc important for the $\Delta$ FosB and CREB behav- ioral phenotypes. As just one example, $\Delta$ FosB increases drug sensitivity in part by increasing GluR2 (GluA2)-containing AMPA receptors (Kelz et al., 1999; Vialou et al., 2010a), whereas CREB decreases drug sensitivity in part by inducing dynorphin (Carlezon et al., 2005), by inducing GluR1 (Olson et al., 2005), and by generating silent synapses via increased levels of NR2Bcontaining NMDA receptors (Brown et al., 2011). Additional work is needed to more completely characterize the range of target genes regulated by $\triangle F$ FosB and CREB in NAc and to investigate the contribution of SRF to these genomic responses to cocaine as well.

\section{Distinct transcriptional mechanisms underlying $\Delta$ FosB induction in addiction and stress models}

A fascinating finding of the present study is that two chronic stimuli-cocaine and stress-that induce $\Delta$ FosB in NAc medium spiny neurons (MSNs) do so via distinct transcriptional mechanisms. Stress induction of $\Delta$ FosB requires $S R F$, with CREB having no effect despite also being activated by stress, whereas cocaine induction of $\Delta$ FosB requires both factors with loss of either factor alone having no effect. One possibility is that different cell types are involved. Although cocaine induction of $\Delta \mathrm{FosB}$ is specific for MSNs that express $\mathrm{D}_{1}$ dopamine receptors, stress induction of $\Delta$ FosB occurs approximately equally in MSNs that express $D_{1}$ receptors and those that express $D_{2}$ receptors (Kelz et al., 1999; Perrotti et al., 2004). However, this cellular specificity would not appear to explain the different roles of CREB and SRF in cocaine versus stress conditions, because we have observed all-or-none phenomena: loss of CREB or SRF alone has no detectable effect on $\Delta$ FosB induction by cocaine.

An alternative possibility is that cocaine and stress induce $\Delta$ FosB in NAc MSNs through the activation of distinct signaling pathways, which differentially affect CREB versus SRF. However, this would not appear to be the case, because both transcription factors are activated in response to cocaine or stress. Both CREB and SRF are activated by postsynaptic $\mathrm{Ca}^{2+}$ signaling (hence synaptic activity), as well as enhanced neurotrophic and ERK signaling (Bading et al., 1993; Xia et al., 1996; Johnson et al., 1997; Chang et al., 2004; Kalita et al., 2006; Knöll and Nordheim, 2009). A recent study points to a role for Elk-1 in cocaine induction of $\Delta$ FosB (Besnard et al., 2011). Elk-1 forms a complex with SRF to bind SREs, further supporting a role for SRF in $\triangle$ FosB induction by cocaine. Alternatively, cocaine activation of the PKA/cAMP pathway activates CREB but does not appear to regulate SRF. Cocaine increases dopamine and neurotrophin signaling in NAc, suggesting that $\Delta$ FosB induction might be dopamine or neurotrophin dependent. In contrast, $\Delta$ FosB is induced in NAc after chronic social defeat stress only in resilient mice (Vialou et al., 2010a), which display normal levels of neurotrophin signaling and firing of ventral tegmental area dopamine neurons that innervate the NAc (Krishnan et al., 2007).

Thus, additional work is needed to understand why some of the same NAc MSNs require SRF only for $\Delta$ FosB induction after stress but both SRF and CREB after cocaine. Our working hypothesis, which now requires direct examination, is that stress and cocaine are associated with other chromatin modifications at the $f o s B$ gene, which influence the inducibility of the gene in response to SRF, CREB, and presumably other factors.

\section{Regulation of basal $\Delta$ FosB expression}

CREB and SRF single or double knock-out has no effect on basal levels of $\Delta$ FosB in NAc. $\Delta$ FosB is expressed at appreciable basal levels uniquely in NAc (and dorsal striatum) compared with 
other brain regions in naive animals (Nye et al., 1995; Perrotti et al., 2008), and such expression levels are important in setting an individual's basal motivational state with respect to natural rewards and stress vulnerability (Wallace et al., 2008; Vialou et al., 2010a). Moreover, basal levels of phospho-CREB and phosphoSRF are relatively low in NAc. These observations indicate that other transcriptional mechanisms are important for maintaining basal $\Delta$ FosB levels but not its induction by cocaine or stress. The fos $B$ gene promoter contains cis-regulatory elements for other transcription factors, such as specific protein 1 and CCAATenhancer binding protein (Lazo et al., 1992), which regulate fos $B$ gene expression in cardiac myocytes (Jindal and Goswami, 2011). The involvement of these or perhaps other factors in maintaining high basal levels of $\triangle \mathrm{FosB}$ in NAc now requires direct investigation.

\section{Conclusions}

Our data support a model in which cocaine exposure activates multiple intracellular pathways involved in the accumulation of $\triangle$ FosB in NAc. These findings also highlight the versatility of CREB and SRF in controlling $\triangle \mathrm{FosB}$, a transcription factor strongly implicated in neuronal adaptations to drugs of abuse and stress. Gaining a better understanding of the interplay between the transcriptional actions of SRF and CREB in regulating cocaine reward will aid in the identification of novel gene targets involved in addiction and may facilitate the future development of more effective therapies.

\section{References}

Bading H, Ginty DD, Greenberg ME (1993) Regulation of gene expression in hippocampal neurons by distinct calcium signaling pathways. Science 260:181-186.

Barrot M, Olivier JD, Perrotti LI, DiLeone RJ, Berton O, Eisch AJ, Impey S, Storm DR, Neve RL, Yin JC, Zachariou V, Nestler EJ (2002) CREB activity in the nucleus accumbens shell controls gating of behavioral responses to emotional stimuli. Proc Natl Acad Sci USA 99:11435-11440.

Besnard A, Bouveyron N, Kappes V, Pascoli V, Pagès C, Heck N, Vanhoutte P, Caboche J (2011) Alterations of molecular and behavioral responses to cocaine by selective inhibition of Elk-1 phosphorylation. J Neurosci 31:14296-14307.

Blendy JA (2006) The role of CREB in depression and antidepressant treatment. Biol Psychiatry 59:1144-1150.

Borges K, Dingledine R (2001) Functional organization of the GluR1 glutamate receptor promoter. J Biol Chem 276:25929-25938.

Brown TE, Lee BR, Mu P, Ferguson D, Dietz D, Ohnishi YN, Lin Y, Suska A, Ishikawa M, Huang YH, Shen H, Kalivas PW, Sorg BA, Zukin RS, Nestler EJ, Dong Y, Schlüter OM (2011) A silent synapse-based mechanism for cocaine-induced locomotor sensitization. J Neurosci 31:8163-8174.

Carlezon WA Jr, Thome J, Olson VG, Lane-Ladd SB, Brodkin ES, Hiroi N, Duman RS, Neve RL, Nestler EJ (1998) Regulation of cocaine reward by CREB. Science 282:2272-2275.

Carlezon WA Jr, Duman RS, Nestler EJ (2005) The many faces of CREB. Trends Neurosci 28:436-445.

Chang SH, Poser S, Xia Z (2004) A novel role for serum response factor in neuronal survival. J Neurosci 24:2277-2285.

Colby CR, Whisler K, Steffen C, Nestler EJ, Self DW (2003) $\Delta$ FosB enhances incentive for cocaine. J Neurosci 23:2488-2493.

Cole RL, Konradi C, Douglass J, Hyman SE (1995) Neuronal adaptation to amphetamine and dopamine: molecular mechanisms of prodynorphin gene regulation in rat striatum. Neuron 14:813-823.

Covington HE 3rd, Maze I, Sun H, Bomze HM, DeMaio KD, Wu EY, Dietz DM, Lobo MK, Ghose S, Mouzon E, Neve RL, Tamminga CA, Nestler EJ (2011) A role for repressive histone methylation in cocaine-induced vulnerability to stress. Neuron 71:656-670.

Dinieri JA, Nemeth CL, Parsegian A, Carle T, Gurevich VV, Gurevich E, Neve RL, Nestler EJ, Carlezon WA Jr (2009) Altered sensitivity to rewarding and aversive drugs in mice with inducible disruption of cAMP response element-binding protein function within the nucleus accumbens. J Neurosci 29:1855-1859.
Dong Y, Green T, Saal D, Marie H, Neve R, Nestler EJ, Malenka RC (2006) CREB modulates excitability of nucleus accumbens neurons. Nat Neurosci 9:475-477.

Iyer D, Belaguli N, Flück M, Rowan BG, Wei L, Weigel NL, Booth FW, Epstein HF, Schwartz RJ, Balasubramanyam A (2003) Novel phosphorylation target in the serum response factor MADS box regulates alpha-actin transcription. Biochemistry 42:7477-7486.

Janknecht R, Hipskind RA, Houthaeve T, Nordheim A, Stunnenberg HG (1992) Identification of multiple SRF N-terminal phosphorylation sites affecting DNA binding properties. EMBO J 11:1045-1054.

Jindal E, Goswami SK (2011) In cardiac myoblasts, cellular redox regulates FosB and Fra-1 through multiple cis-regulatory modules. Free Radic Biol Med 51:1512-1521.

Johnson CM, Hill CS, Chawla S, Treisman R, Bading H (1997) Calcium controls gene expression via three distinct pathways that can function independently of the Ras/mitogen-activated protein kinases (ERKs) signaling cascade. J Neurosci 17:6189-6202.

Kalita K, Kharebava G, Zheng JJ, Hetman M (2006) Role of megakaryoblastic acute leukemia-1 in ERK1/2-dependent stimulation of serum response factor-driven transcription by BDNF or increased synaptic activity. J Neurosci 26:10020-10032.

Kelz MB, Chen J, Carlezon WA Jr, Whisler K, Gilden L, Beckmann AM, Steffen C, Zhang YJ, Marotti L, Self DW, Tkatch T, Baranauskas G, Surmeier DJ, Neve RL, Duman RS, Picciotto MR, Nestler EJ (1999) Expression of the transcription factor deltaFosB in the brain controls sensitivity to cocaine. Nature 401:272-276.

Knöll B, Nordheim A (2009) Functional versatility of transcription factors in the nervous system: the SRF paradigm. Trends Neurosci 32:432-442.

Krishnan V, Han MH, Graham DL, Berton O, Renthal W, Russo SJ, Laplant Q, Graham A, Lutter M, Lagace DC, Ghose S, Reister R, Tannous P, Green TA, Neve RL, Chakravarty S, Kumar A, Eisch AJ, Self DW, Lee FS, et al. (2007) Molecular adaptations underlying susceptibility and resistance to social defeat in brain reward regions. Cell 131:391-404.

Larson EB, Graham DL, Arzaga RR, Buzin N, Webb J, Green TA, Bass CE, Neve RL, Terwilliger EF, Nestler EJ, Self DW (2011) Overexpression of CREB in the nucleus accumbens shell increases cocaine reinforcement in self-administering rats. J Neurosci 31:16447-16457.

Lazo PS, Dorfman K, Noguchi T, Mattéi MG, Bravo R (1992) Structure and mapping of the fosB gene. FosB downregulates the activity of the fosB promoter. Nucleic Acids Res 20:343-350.

Lee TI, Jenner RG, Boyer LA, Guenther MG, Levine SS, Kumar RM, Chevalier B, Johnstone SE, Cole MF, Isono K, Koseki H, Fuchikami T, Abe K, Murray HL, Zucker JP, Yuan B, Bell GW, Herbolsheimer E, Hannett NM, Sun K, et al. (2006) Control of developmental regulators by Polycomb in human embryonic stem cells. Cell 125:301-313.

Loweth JA, Baker LK, Guptaa T, Guillory AM, Vezina P (2008) Inhibition of CaMKII in the nucleus accumbens shell decreases enhanced amphetamine intake in sensitized rats. Neurosci Lett 444:157-160.

Marin MT, Berkow A, Golden SA, Koya E, Planeta CS, Hope BT (2009) Context-specific modulation of cocaine-induced locomotor sensitization and ERK and CREB phosphorylation in the rat nucleus accumbens. Eur J Neurosci 30:1931-1940.

Matamales M, Girault JA (2011) Signaling from the cytoplasm to the nucleus in striatal medium-sized spiny neurons. Front Neuroanat 5:37.

Maze I, Covington HE 3rd, Dietz DM, LaPlant Q, Renthal W, Russo SJ, Mechanic M, Mouzon E, Neve RL, Haggarty SJ, Ren Y, Sampath SC, Hurd YL, Greengard P, Tarakhovsky A, Schaefer A, Nestler EJ (2010) Essential role of the histone methyltransferase G9a in cocaine-induced plasticity. Science 327:213-216.

McClung CA, Nestler EJ (2003) Regulation of gene expression and cocaine reward by CREB and DeltaFosB. Nat Neurosci 6:1208-1215.

Nestler EJ (2001) Molecular basis of long-term plasticity underlying addiction. Nat Rev Neurosci 2:119-128.

Nestler EJ (2004) Molecular mechanisms of drug addiction. Neuropharmacology 47 [Suppl 1]:24-32.

Nestler EJ (2008) Review. Transcriptional mechanisms of addiction: role of DeltaFosB. Philos Trans R Soc Lond B Biol Sci 363:3245-3255.

Nye HE, Hope BT, Kelz MB, Iadarola M, Nestler EJ (1995) Pharmacological studies of the regulation of chronic FOS-related antigen induction by cocaine in the striatum and nucleus accumbens. J Pharmacol Exp Ther 275:1671-1680.

Olson VG, Zabetian CP, Bolanos CA, Edwards S, Barrot M, Eisch AJ, Hughes 
T, Self DW, Neve RL, Nestler EJ (2005) Regulation of drug reward by cAMP response element-binding protein: evidence for two functionally distinct subregions of the ventral tegmental area. J Neurosci 25:5553-5562.

Parkitna JR, Bilbao A, Rieker C, Engblom D, Piechota M, Nordheim A, Spanagel R, Schütz G (2010) Loss of the serum response factor in the dopamine system leads to hyperactivity. FASEB J 24:2427-2435.

Peakman MC, Colby C, Perrotti LI, Tekumalla P, Carle T, Ulery P, Chao J, Duman C, Steffen C, Monteggia L, Allen MR, Stock JL, Duman RS, McNeish JD, Barrot M, Self DW, Nestler EJ, Schaeffer E (2003) Inducible, brain region specific expression of a dominant negative mutant of c-Jun in transgenic mice decreases sensitivity to cocaine. Brain Res 970:73-86.

Perrotti LI, Hadeishi Y, Ulery PG, Barrot M, Monteggia L, Duman RS, Nestler EJ (2004) Induction of $\Delta$ FosB in reward-related brain structures after chronic stress. J Neurosci 24:10594-10602.

Perrotti LI, Weaver RR, Robison B, Renthal W, Maze I, Yazdani S, Elmore RG, Knapp DJ, Selley DE, Martin BR, Sim-Selley L, Bachtell RK, Self DW, Nestler EJ (2008) Distinct patterns of DeltaFosB induction in brain by drugs of abuse. Synapse 62:358-369.

Ramanan N, Shen Y, Sarsfield S, Lemberger T, Schütz G, Linden DJ, Ginty DD (2005) SRF mediates activity-induced gene expression and synaptic plasticity but not neuronal viability. Nat Neurosci 8:759-767.

Renthal W, Kumar A, Xiao G, Wilkinson M, Covington HE 3rd, Maze I, Sikder D, Robison AJ, LaPlant Q, Dietz DM, Russo SJ, Vialou V, Chakravarty S, Kodadek TJ, Stack A, Kabbaj M, Nestler EJ (2009) Genomewide analysis of chromatin regulation by cocaine reveals a role for sirtuins. Neuron 62:335-348.

Robison AJ, Vialou V, Mazei-Robison M, Kourrich S, Ahn F, Russo S, Thomas MJ, Nestler EJ (2011) Chronic cocaine engages a feed-forward loop involving $\triangle$ Fosb and CaMKII in the nucleus accumbens. Soc Neurosci Abstr 37:9093.

Russo SJ, Wilkinson MB, Mazei-Robison MS, Dietz DM, Maze I, Krishnan V, Renthal W, Graham A, Birnbaum SG, Green TA, Robison B, Lesselyong A, Perrotti LI, Bolaños CA, Kumar A, Clark MS, Neumaier JF, Neve RL, Bhakar AL, Barker PA, Nestler EJ (2009) Nuclear factor $\kappa$ B signaling regulates neuronal morphology and cocaine reward. J Neurosci 29:3529-3537.

Sakai N, Thome J, Newton SS, Chen J, Kelz MB, Steffen C, Nestler EJ, Duman
RS (2002) Inducible and brain region-specific CREB transgenic mice. Mol Pharmacol 61:1453-1464.

Simpson JN, Wang JQ, McGinty JF (1995) Repeated amphetamine administration induces a prolonged augmentation of phosphorylated cyclase response element-binding protein and Fos-related antigen immunoreactivity in rat striatum. Neuroscience 69:441-457.

Turgeon SM, Pollack AE, Fink JS (1997) Enhanced CREB phosphorylation and changes in c-Fos and FRA expression in striatum accompany amphetamine sensitization. Brain Res 749:120-126.

Ulery-Reynolds PG, Castillo MA, Vialou V, Russo SJ, Nestler EJ (2009) Phosphorylation of DeltaFosB mediates its stability in vivo. Neuroscience 158: 369-372.

Valjent E, Corvol JC, Pages C, Besson MJ, Maldonado R, Caboche J (2000) Involvement of the extracellular signal-regulated kinase cascade for cocaine-rewarding properties. J Neurosci 20:8701-8709.

Valverde O, Mantamadiotis T, Torrecilla M, Ugedo L, Pineda J, Bleckmann S, Gass P, Kretz O, Mitchell JM, Schütz G, Maldonado R (2004) Modulation of anxiety-like behavior and morphine dependence in CREBdeficient mice. Neuropsychopharmacology 29:1122-1133.

Vialou V, Robison AJ, Laplant QC, Covington HE 3rd, Dietz DM, Ohnishi YN, Mouzon E, Rush AJ 3rd, Watts EL, Wallace DL, Iñiguez SD, Ohnishi YH, Steiner MA, Warren BL, Krishnan V, Bolaños CA, Neve RL, Ghose S, Berton O, Tamminga CA, Nestler EJ (2010a) DeltaFosB in brain reward circuits mediates resilience to stress and antidepressant responses. Nat Neurosci 13:745-752.

Vialou V, Maze I, Renthal W, LaPlant QC, Watts EL, Mouzon E, Ghose S, Tamminga CA, Nestler EJ (2010b) Serum response factor promotes resilience to chronic social stress through the induction of $\triangle$ FosB. J Neurosci 30:14585-14592.

Wallace DL, Vialou V, Rios L, Carle-Florence TL, Chakravarty S, Kumar A, Graham DL, Green TA, Kirk A, Iñiguez SD, Perrotti LI, Barrot M, DiLeone RJ, Nestler EJ, Bolaños-Guzmán CA (2008) The influence of $\Delta$ FosB in the nucleus accumbens on natural reward-related behavior. J Neurosci 28:10272-10277.

Xia Z, Dudek H, Miranti CK, Greenberg ME (1996) Calcium influx via the NMDA receptor induces immediate early gene transcription by a MAP kinase/ERK-dependent mechanism. J Neurosci 16:5425-5436. 